\title{
Soil Erosion Risk Assessment in Nashe Dam Reservoir Using Remote Sensing, GIS and RUSLE Model Techniques in Horro Guduru Wollega Zone, Oromia Region, Ethiopia
}

\author{
Ayana Abera Beyene \\ Surveying Engineering, Institute of Technology, Wollega University, Nekemte, Ethiopia \\ Emailaddress: \\ ayanabera2004@gmail.com
}

\section{To cite this article:}

Ayana Abera Beyene. Soil Erosion Risk Assessment in Nashe Dam Reservoir Using Remote Sensing, GIS and RUSLE Model Techniques in Horro Guduru Wollega Zone, Oromia Region, Ethiopia. Journal of Civil, Construction and Environmental Engineering. Vol. 4, No. 1, 2019, pp. 1-18. doi: 10.11648/j.jccee.20190401.11

Received: January 1, 2019; Accepted: February 14, 2019; Published: March 11, 2019

\begin{abstract}
Soil degradation is wide spread and serious throughout the Ethiopian Highlands. It is also a major watershed problem in many developing countries causing significant loss of soil fertility, loss of productivity and environmental degradation. This research has, therefore, been carried out to evaluate the soil erosion risk and quantify the major land use land cover changes over the past 20 years (1996-2016) in the Nashe watershed. The research integrates the Revised Universal Soil Loss Equation (RUSLE) with a Geographic Information System (GIS) and Remote Sensing (RS) to quantify the potential soil erosion risk and land use land cover changes. Rainfall data, soil data, DEM data and satellite image were used as input data sets to generate RUSLE factor values. Raster calculator was used to interactively calculate potential soil loss and prepare soil erosion risk map. For the land use land cover change calculation two satellite images of two year interval ( Landsat TM 1996 and Landsat 2016) has been utilized. As a result the potential soil erosion risk and land use land cover map of 1996 and 2016 of the study area was generated. The result showed that the potential annual soil loss of the watershed ranges from 0.00 to $243 . .065$ ton/ha/yr. and the mean annual soil loss rate is $45.7 \mathrm{ton} / \mathrm{ha} / \mathrm{yr}$. Concerning the land use land cover change Grass land decline from (8.85\%) to $(6.85 .4 \%)$, open forest changes from $(47.10 \%)$ to $(22.75 \%)$ and settlement land changes from $(4.42 \%)$ to $(7.59 \%)$. On the contrary farm land changes from $(27.18 \%)$ to $(45.55 \%)$, bare lands increase from $(5.40 \%)$ to $(5.55 \%)$ and water body changes from $(7.06 \%)$ to $(12.10 \%)$. By the LULC analysis it has been found that the grass land and forest land declined from $1996-2016$. On other hand, the rest of the land cover types have increased.
\end{abstract}

Keywords: Nashe Dam, Soil Erosion Risk, Watershed, RUSLE, GIS

\section{Introduction}

Soil degradation by accelerated water and wind-induced erosion is a serious problem and will remain so during the $21 \mathrm{st}$ century, especially in developing countries of tropics and subtropics.

Worldwide degradation of agricultural land by erosion, salinization, and water logging is causing the irretrievable loss of an estimated 6 million hectares each year. Depletion of soils and water resources are a major hazard in the third world. As cited in Abey (2007), in Ethiopia land degradation in the form of soil erosion and declining fertility is serious challenge to agricultural productivity and economic growth [4]. Soil conservation is a significant socio-environmental issue that reflects the wellbeing of the people in every country in the world and also information on the factor leading to soil erosion can be used as a perspective for the development of appropriate land use plan. In order to predict and also prevent soil erosion it is necessary to assess the potential and also the actual risks of soil erosion. Many attempts have been made on the modeling of soil erosion. There are wide varieties of models available for assessing soil erosion risk. Erosion models can be classified in a number of ways. All methods could be divided as expert-based and model-based methods. One may make a subdivision based on the time scale for which a model can be used: some models are designed to predict long-term annual soil losses, while others predict single storm losses (event-based). Alternatively, a distinction can be made 
between lumped models that predict erosion at a single point, and spatially distributed models. Another useful division is the one between empirical and physically-based models.

Thus, remote sensing (RS) and GIS have resulted in great progress in the research of soil erosion and soil and water conservation since the end of 1980s. Estimation of soil erosion and its spatial distribution using RS and GIS techniques were performed with reasonable costs and better accuracy in larger areas to face up to land degradation and environmental deterioration. Generating accurate environmental risk maps in GIS environment is very important to locate the areas with high environmental risks and to develop adequate risk prevention techniques [12] While Remote Sensing (RS) has proved to be a useful, inexpensive and effective tool in soil erosion risk mapping. Remote Sensing can provide the data necessary for erosion modeling within a GIS (Leh, 2011). In this study; an integrated Remote Sensing-GIS and Revised Universal Soil Loss Equation (RUSLE) has been used to assess the annual soil loss risk.

\subsection{Statement of the Problem}

The Amerti-Neshe hydropower dam constructed over the Nashe River had a long history. Its survey dated back to 1950's during the era of Imperial Haile Silase regime. A man of the study area called Ato Bekela Merga (age 65) witnessed that during the era of Imperial Haile Silase regime, Government made discussion over the issue of the dam with local land lords of the area on a meeting held at Nekemte town. Later, based on the consensus made, a crew of higher officials together with some foreigners came to the area and marked on the ground where the dam was to be constructed over the Nashe river and driven a stake in to the ground marked with flag to delineate the reservoir boundary. Before the dam was built, the people living in the area that is now inundated were not taken into consideration: they were neither resettled nor financially compensated. Assefa (1994) mentions that the then Ethiopian Electric Light and Power Authority attempted to compensate only the landlords who officially owned most of the land and whose settlement area and trees were submerged, but the majority of farmers were not considered. It is not exactly known how many households were displaced from their dwellings. Some people possibly migrated to areas outside the Nashe watershed to make a living, while others stayed within the watershed. A survey among 120 households in Nashe revealed that $14 \%$ had to relocate in the watershed as a result of the dam construction. The majority of these households had resettled themselves in the hilly areas of the watershed, owning $23 \%$ less land and $24 \%$ fewer livestock units. Others probably left the area and moved to towns or started farming in neighboring watersheds. The migration of households towards the higher and steeper parts of the watershed may have further aggravated the soil erosion problems which are a serious problem in the Ethiopian highland areas, threatening the agricultural sector [5] and causing increased sedimentation of reservoirs and lakes. Unfortunately, there is very little reliable information on the spatial dynamics of the land use types, the factors driving land use changes, and the implications of these changes on soil degradation. Such information is, however, very important for planning watershed-based development projects such as soil and water conservation (SWC) programs.

\subsection{Objectives of the Study}

\subsubsection{General Objective}

The general objective of the study is to assess the extent of soil erosion risk on Nashe Dam watershed and to investigate the land use changes.

\subsubsection{Specific Objectives}

The specific objectives are outlined to:

1. Estimate the average annual soil loss from the watershed.

2. Develop a soil loss intensity map of the study area.

3. Analyze and quantify the land use land cover change over the past twenty years (1996-2016).

4. Determine the relationship of land cover and Elevation in connection to its susceptibility to erosion.

\section{Research Metheodology}

\subsection{Location of Study Area}

The study area is conducted at Abay Choman District of Horro Guduru Wollega zone, Oromia regional state, Ethiopia. The study area is located at about $310 \mathrm{~km}$ west of Addis Ababa (the capital city of the country). The study area is located between $09^{\circ} 29^{\prime} 30^{\circ} \mathrm{N}$ to $09^{\circ} 46^{\circ} 00^{\circ} \mathrm{N}$ and $37^{\circ} 08^{\prime} 15^{\prime \prime} \mathrm{E}$ to $37^{\circ} 16^{\prime} 45^{\prime \prime} \mathrm{E}$ and at an altitude of approximately 2296 m.a.sl geographical coordinates. The area has one long rainy season extending from March to Mid-October (Olana, 2006). According to the 2010/11 annual report of Abay choman district the monthly annual rainfall ranges from $1000-2400 \mathrm{~mm}$. Nashe dam is constructed on the Nashe River in the village of EGU ABAY that is located in Abbay choman woreda. This dam is constructed for hydropower and irrigation purposes.

The Amerti-Neshe hydropower dam was constructed on the Neshe River which is one of the major river of the Finchia valley basin situated along the common border of Horro and Abay- Chomen districts of Horro Guduru Wollega Zone. There are many tributary rivers flowing into the Neshe River amongst which Aseti, Babbo, Nugulo, Chige, Nebas, Defas, and Torben are the major ones.

The Finchaa-Amerti-Neshe Multipurpose Project was constructed by Ethiopian Electric Power Corporation (EEPCO) by the contractor named China Gezhouba Group Corporation (CGGC) with the total outlay of more than 2.63 billion birr out of which $85 \%$ was covered by loan of Export Import Bank of China and the $15 \%$ with Ethiopian government (FANMHO Report, 2011). The reservoir occupied an area of 2920 hectares of land and has a total storage volume of $4.48 * 108 \mathrm{~m} 3$. The project was constructed to generate hydroelectric power of $97 \mathrm{MW}$ from two units. After generating the intended electric power, the water will 
irrigate more than 6000 hectares of land for sugar cane downstream in the Finchea valley, and also 0.75 hectares of farmland for each household affected by the dam when they resettle. Dam construction was the major component of the project, whose construction was started in 2008 and completed in January, 2010 and the reservoir started to accumulate water that is necessary to generate electric power [8].

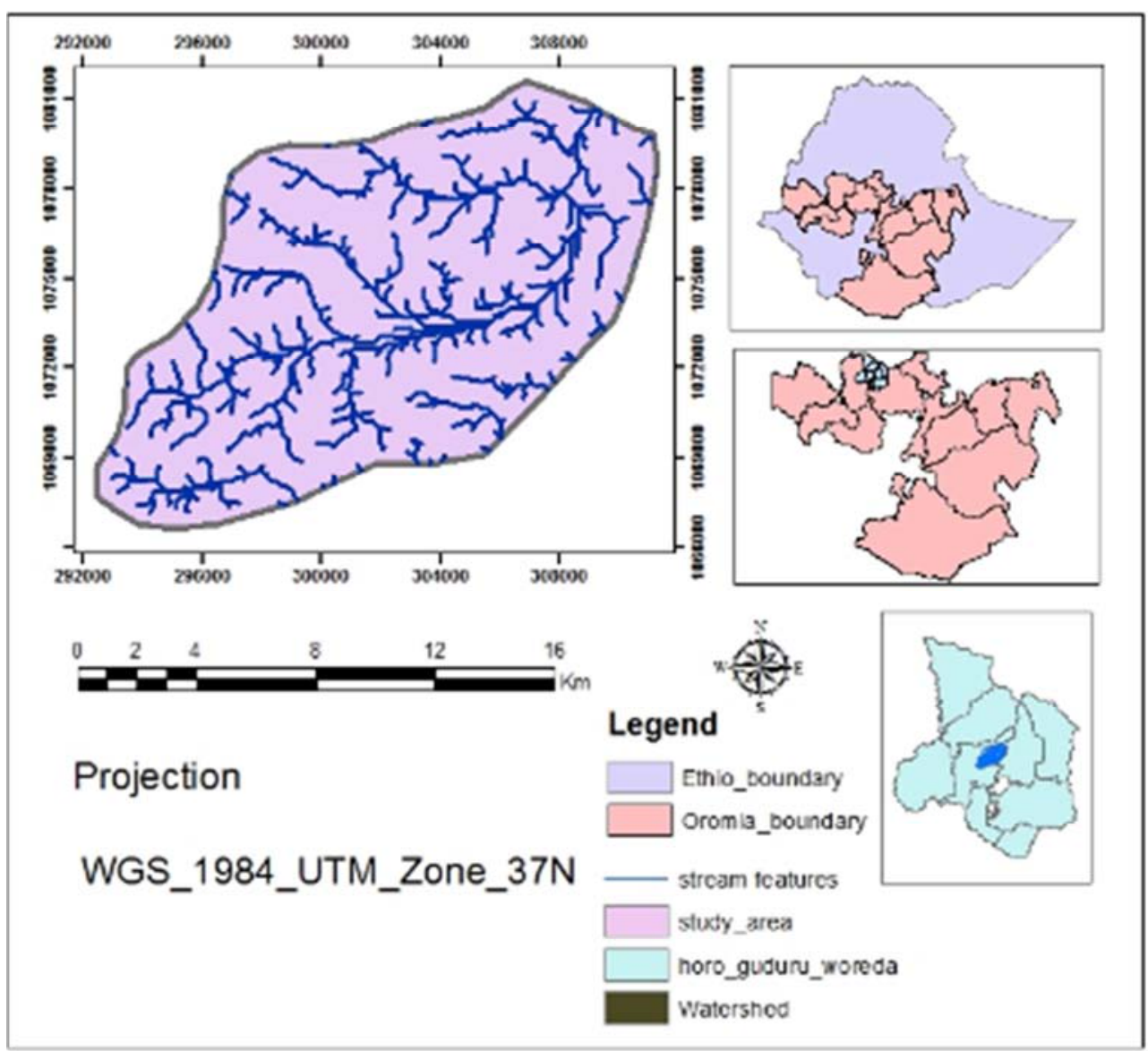

Figure 1. Location of Study area.

\subsection{Methods of Soil Erosion Risk Analysis}

For Nashe Dam watershed, the relevant maps were created using ArcGIS 10.1 and ERDAS Imagine 2014 software tools. Satellite imagery, DEM, Soil and Rainfall of the study area was used as primary data source. The rainfall distribution map was prepared from Ethiopian rainfall data. The land use/land cover map was extracted from LANDSAT (Satellite imagery) satellite image using ERDAS Imagine 2014 software and the data was classified using GIS software. The slope map and Elevation map was extracted from DEM of the study area using GIS spatial analyst tool.

The study was conducted using Revised Universal Soil Loss Equation (RUSLE) model for soil loss methods. A personal geo-database was created in Arc Catalog and dataset was created for the Study area with the spatial reference of WGS 1984 UTM Zone $37 \mathrm{~N}$ to arrange, store and to have the same projection of coordinate. In addition to these personal geo-database is to protect the data from lost and easy access in the GIS tool. The thematic maps of Rainfall map, Slope map, Elevation map, land use land cover map, and soil map were prepared using Raster calculation Method in ArcGIS software by multiplying all the parameters. The data layers have been integrated in GIS spatial analyst by Overlaying Analysis using Raster calculator or multiplying all causative factor using Raster calculator to obtain the soil erosion map.

The overall methodology involved the use of the RUSLE in a GIS environment, with factors obtained from meteorological stations, soil surveys, topographic maps, satellite images, digital elevation model and results of other relevant studies. Individual GIS layers were built for each factor in the RUSLE and combined by cell-grid modeling procedures in ArcGIS to predict soil loss in a spatial domain (Eastman, 1999). The expected soil loss potential (erosion hazard) expressed as tone per hectare per year for the study area was determined using the RUSLE model in a GIS environment. The Universal Soil Loss Equation (USLE) developed by [5] is the most frequently used empirical soil erosion model worldwide. More recently, [14] has modified the USLE into a Revised Universal Soil Loss Equation (RUSLE) by introducing improved means of computing the soil erosion factors.

The USLE has been used widely all over the world either in the same or modified forms.[10], also used this model to assess soil erosion in Ethiopia. He even modified some factors of the USLE for Ethiopian conditions. Three of the most 
significant modifications include R (rainfall erosivity index), $\mathrm{C}$ (land cover) and $\mathrm{P}$ (management) factors. This was a valuable input to this research and other erosion research in Ethiopia since the 1980's. However, the available information in this regard is still generalization of the realities in different localities and doesn't show specific conditions. Therefore, there is a need to conduct a detailed and extensive assessment of erosion hazard by considering the various site specific erosion factors into considerations. The control factors of soil erosion, namely: climate, soils, vegetation cover, topography and management are combined in the empirical Revised Universal Soil Loss Equation [14]. The model estimates sheet and rill erosion as a function of six major factors:

$$
\mathrm{A}=\mathrm{R} * \mathrm{~K} * \mathrm{LS}^{*} \mathrm{C} * \mathrm{P}
$$

Where $\mathrm{A}$ is the average annual soil loss due to water erosion $\left(\mathrm{t} \mathrm{ha} \mathrm{y}^{-1}\right), \mathrm{R}$ is the rainfall and runoff erosivity factor, $\mathrm{K}$ is the soil erodibility factor, LS is the slope length and slope steepness factor, $\mathrm{C}$ is the crop management or land cover factor and $\mathrm{P}$ is the erosion control practice factor.

\subsection{Methods of Land Use Land Cover Change Detection}

Multi-temporal (1996 and 2016) satellite imageries of the study area have been imported to ERDAS 2014 image processing software. Image pre-processing, enhancement, classification were applied on the raw image. The classified images have been used in the extraction of information on land cover condition and quantification of changes over the last two decades using multi temporal GIS analysis. The land cover conditions of the two different periods (1996 and 2016) have been compared and change has been detected and quantified by post classification comparison method.

\subsubsection{Image Processing}

Landsat image TM (1996) and (2016) was used for this study. For each of them digital image processing operations such as image restoration, geo-referencing, image enhancement and image classification (unsupervised and supervised) have been done using ERDAS Imagine 2014 image processing software. Area of interest is delineated using ERDAS IMAGIN 2014 software and study area is digitized using Arc GIS 10.1 software from topographic map of scale 1:50,000 after the topographic map is geo-referenced or projected to Datum: UTM/WGS 1984, 37N. Then, subset was prepared for the imageries based on area of interest (AOI).

\subsubsection{Image Classification}

Image classification is necessary to convert image data to thematic data. According to [11], the overall objective of image classification procedures is to automatically categorize all pixels in an image into land use land cover classes. Notice that data are transformed into information. Multispectral classification is one of the most often used methods of information extraction (Jensen, 1996)). In classifying the images, both unsupervised and supervised image classifications techniques were applied. The unsupervised was done before field work. Supervised classification requires a prior knowledge of the scene area in order to provide the software with unique training classes. It is up to the user to define the original pixels that contain similar spectral classes representing certain land cover classes. Correspondingly, representative points believed to represent the various land cover classes were marked using GARMIN GPS during the field visit. These points were used to sample representative signatures for various land cover types identified during the field visit. Following this, supervised land use and land cover classification has been carried out using ERDAS Imagine software from 2016 Land sat Satellite image. The maximum likelihood image Classification was utilized for the supervised classification. By having applied the techniques of image classification, land use and land cover types have been classified so as to use the classified images as inputs for generating crop management $(\mathrm{C})$ factor and support practice (P) factor of the Revised Universal Soil Loss Equation. With the help of visual interpretation elements and the different reflection characteristics of the features in the satellite image of 2016, the study area has been classified into six land use and land cover classes, namely, farm land, bare lands, settlements, grass land, Water body, and forest lands.

\subsubsection{Accuracy Assessment}

Accuracy assessment is a general term for comparing the classification to geographical data that are assumed to be true, in order to determine the accuracy of the classification process. To assess the classification accuracy, confusion matrix was employed. The confusion/error matrix consists of rows and columns. The rows represent the classification values and the column represents facts from the field. The diagonal line of the error matrix represents the number of pixels that were correctly classified. The overall accuracy index is produced by dividing all the pixels correctly classified by the total number of pixels in the matrix. The producer accuracy index is produced by dividing the number of correctly classified pixels that belong to a class by the sum of the values of the column of the same class. The user accuracy index is produced by dividing the total number of correctly classified pixels that belong to a class by the sum of the values of the rows of the same class. By having this, in this study the overall classification accuracy is $(5+4+12+4+29+16) / 80$ which is equal to 0.875 or 87.5 percent (Table )

Table 1. Classification of Landuse landclasses.

\begin{tabular}{|c|c|c|c|c|c|c|c|}
\hline Classified Data & Grass land & Bare lands & Forest land & Water bodies & Settlement & Agricultural lands & Row Total \\
\hline Grass lands & 5 & 0 & 0 & 0 & 0 & 0 & 5 \\
\hline Bare lands & 0 & 4 & 1 & 0 & 0 & 0 & 5 \\
\hline Forest land & 0 & 0 & 12 & 0 & 0 & 1 & 13 \\
\hline Water bodies & 0 & 0 & 0 & 4 & 0 & 0 & 4 \\
\hline
\end{tabular}




\begin{tabular}{llllllll}
\hline Classified Data & Grass land & Bare lands & Forest land & Water bodies & Settlement & Agricultural lands & Row Total \\
\hline Settlement & 0 & 0 & 3 & 0 & 29 & 4 & 36 \\
Agriculture lands & 1 & 0 & 0 & 0 & 0 & 16 & 17 \\
Column Total & 6 & 4 & 16 & 4 & 29 & 21 & 80 \\
\hline
\end{tabular}

Kappa coefficient $=\frac{(\text { Total } * \text { sum of correct })-\text { sum of the all }(\text { row total } * \text { column total })}{\text { Total squared }- \text { sum of the all }(\text { row total } * \text { column total })}$

The overall classification accuracy of 83.07 and overall Kappa statistics of 0.8307 was achieved, which is feasible for further application. The kappa coefficient lies typically on a scale between 0 and 1, where the latter indicates complete agreement, and is often multiplied by 100 to give percentage measure of classification accuracy. Kappa value is characterized in to three grouping: value greater than 0.8 represents strong agreement, $0.4-0.8$ represents moderate agreement and that of less than 0.4 is considered as poor agreement. The reasons for the errors may include the similarity of reflectance of settlement, grazing land and cultivated areas. In addition, the fast land use land cover dynamic nature of the area may also introduce the classification error.

\section{Data Sources and Methodology}

\subsection{Data Sources}

For this study various basic primary and secondary input data were collected from different sources. For the land use/land cover analysis purpose, Landsat satellite images, ASTER DEM, Topomap of the study area (1:50000) purchased from Ethiopian mapping agency, Soil map (shape file, 1:250,000) collected from Oromia water works design and supervision enterprise and rainfall from Metrological agency were used.

\subsubsection{Precipitation (Rainfall) Data}

There is Nashe metrological station on the study watersheds as a result of this, ten stations were used which are near to the watershed. These ten stations were Fincha, Shambu, Alibo, Gida Ayana, Homi, Jarmet, Kombolcha, Gebete, Hareto and Kachisi. The monthly amounts of rainfall (28-30 Years) and average annual rainfall for these stations were collected from National Metrology Agency. The annual rain fall was interpolated from these eleven points observation in Arc GIS 10.1 by spatial analyst tool and the following rainfall map is produced (Figure 2).

Table 2. Mean Annual Rainfall of the gauging stations.

\begin{tabular}{llll}
\hline station & latitude & longitude & Mean annual rainfall (mm) \\
\hline shambu & 9.5712 & 37.12117 & 1443 \\
Alibo & 9.88633 & 37.074 & 1215.79 \\
Kombolcha & 9.502333 & 37.47267 & 1252.22 \\
Fincha & 9.57 & 37.37033 & 1614.46 \\
Gebete & 9.38383 & 37.4092 & 1066.16 \\
Hareto & 9.35 & 37.12 & 1168.63 \\
Homi & 9.621333 & 37.24117 & 1524.78 \\
Jarmet & 9.8 & 37.01667 & 1242.8 \\
Nashe & 9.72333 & 37.26833 & 1508.97 \\
Kachisi & 9.583333 & 37.86 & 1625.87 \\
Gida Ayana & 9.86667 & 36.61667 & 1498.34 \\
\hline
\end{tabular}

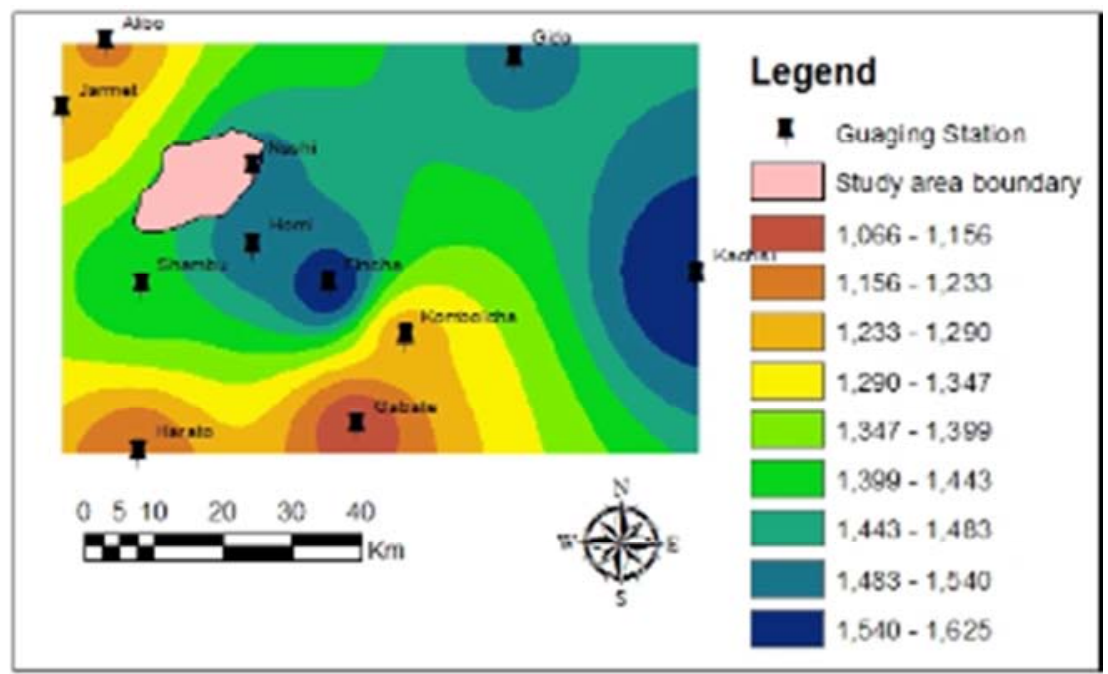

Figure 2. Meteorological Station and Interpolation result map. 


\subsubsection{Geology and Soil Types}

According to the Ethiopian physiographic region division, the study area is situated in the upper Fincha part of the valley system and adjoining the plateau lands of the central high lands. The dominant landscapes of Nashe Dam watershed area are flat, gently undulating plains and mountainous which elevation range from 1907 to 2577 m.a.s 1 .

According to FAO [8] soil classification major soil types of the area are six types of soils in the catchment. These soils are Vertisols, Leptosol, Luvisol and Cambisol. Vertisol is the predominant soil type (Figure 3) which, is found in almost all parts of the watershed. Vertisols are soils having, after the upper $20 \mathrm{~cm}$ have been mixed, 30 percent or more clay in all horizons to a depth of at least 50 $\mathrm{cm}$. Vertisols have A (B) C-profiles; the Ahorizon comprises both the surface mulch (crust) and the underlying structured horizon that changes only gradually with depth.
Dry Vertisols have a very hard consistence; wet Vertisols are very plastic and sticky.

Luvisols characterized a marked textural differentiation within the soil profile, with the surface horizon being depleted of clay and with accumulation of clay in a subsurface 'Argic' horizon. Luvisols have typically a brown to dark brown surface horizon over a reddish brown to strong brown or red argic subsurface horizon and exist on hilly part of the study area.

Cambisols are soils with initial stage of soil formation or weakly developed soils relating to their parent material and exist in all part of the watershed. Leptosols have continuous hard rock within $25 \mathrm{~cm}$ from the soil surface; or a mollic horizon with a thickness between 10 and $25 \mathrm{~cm}$ directly overlying material. Leptosols are very shallow soils over hard rock material but also deeper soils that are extremely gravelly or stony. They are found particularly in hilly to mountainous area in Nashe Reservoir watershed (Figure 3).

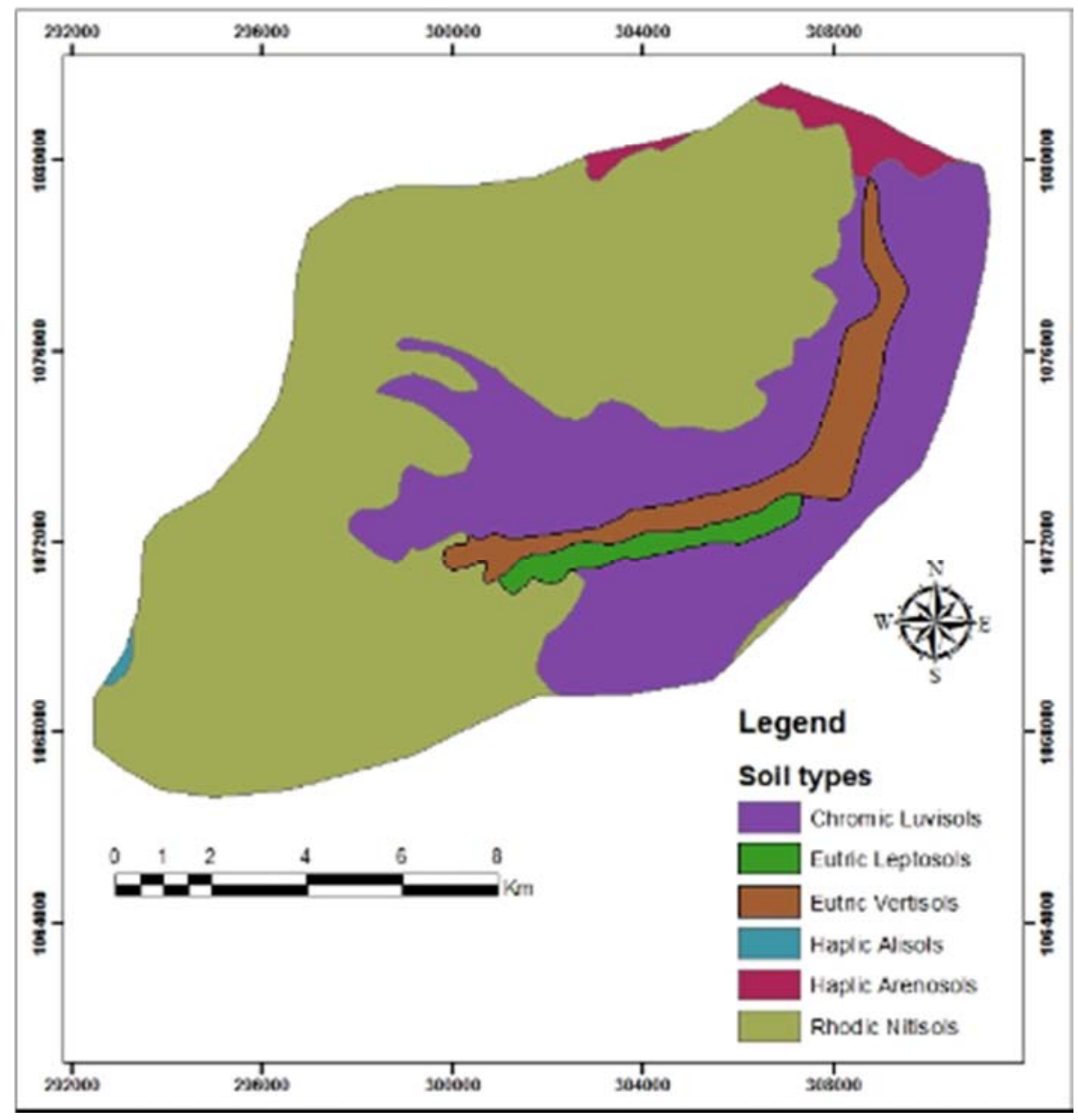

Figure 3. Soil types of the study area.

\subsubsection{The Digital Elevation Model (DEM)}

Digital Elevation Models do play a fundamental role in mapping. The digital description of the three dimensional surface is important for several applications. The DEM files may be used in terrain analysis, with the generation of graphics displaying slope, direction of slope (aspect), and terrain profiles between designated points. The DEM for this study is extracted from Global Land Cover Facility (www.landcover.org) and the satellite imagery is from Shuttle Radar Topography Mission (SRTM) with 30 meter resolution and used to develop topographic parameters such as slope gradient, slope length (slope map). 


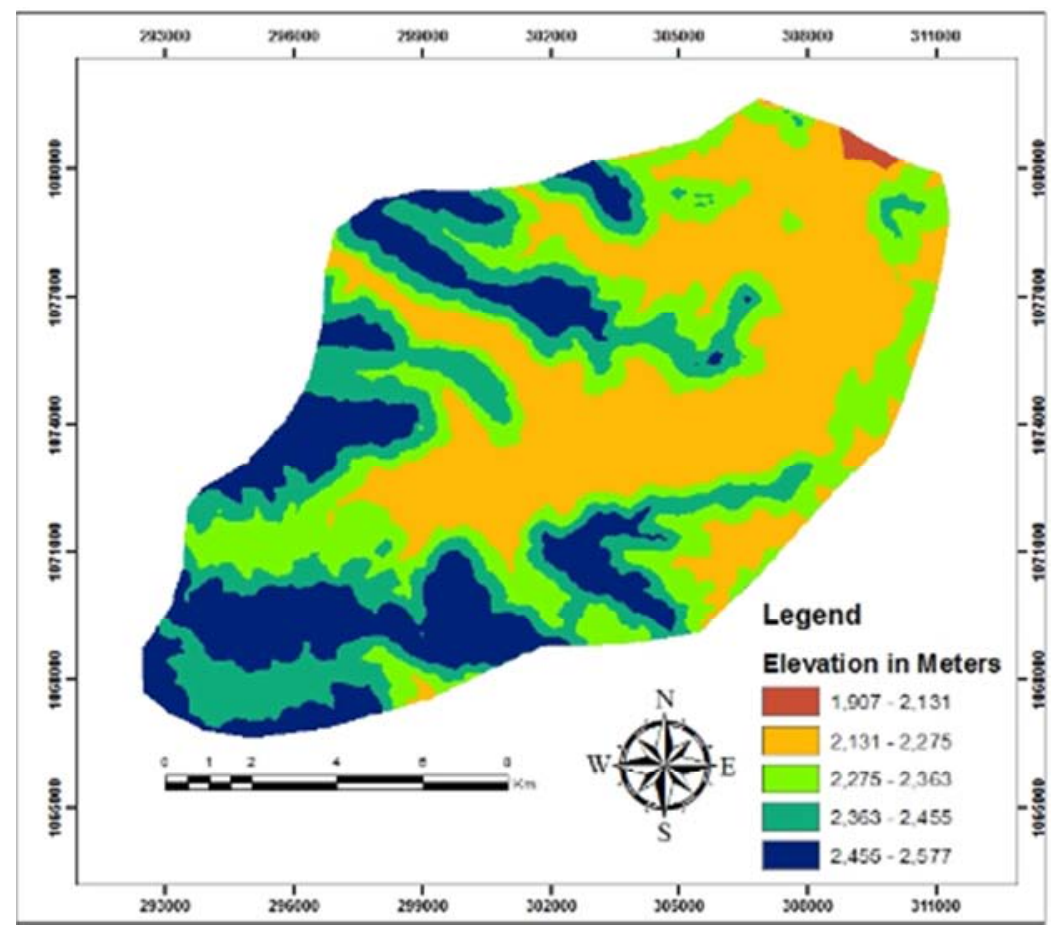

Figure 4. Elevation of the study Area.

\subsubsection{Land use and Land cover Data}

The Landsat TM 1996 and 2016 satellite images have been collected from Ethiopian Mapping Agency which was used to classify the current and twenty years back land use and land cover map of the study watershed. The image has 30 X 30 meter resolutions. Ground truth data were collected from the field to verify the classified image and to collect the necessary land use land cover data for training area delineation and accuracy assessment. Garmin GPS have employed to collect Ground Control Points (GCPs). The ground truth data collection was similar season of image acquisition.

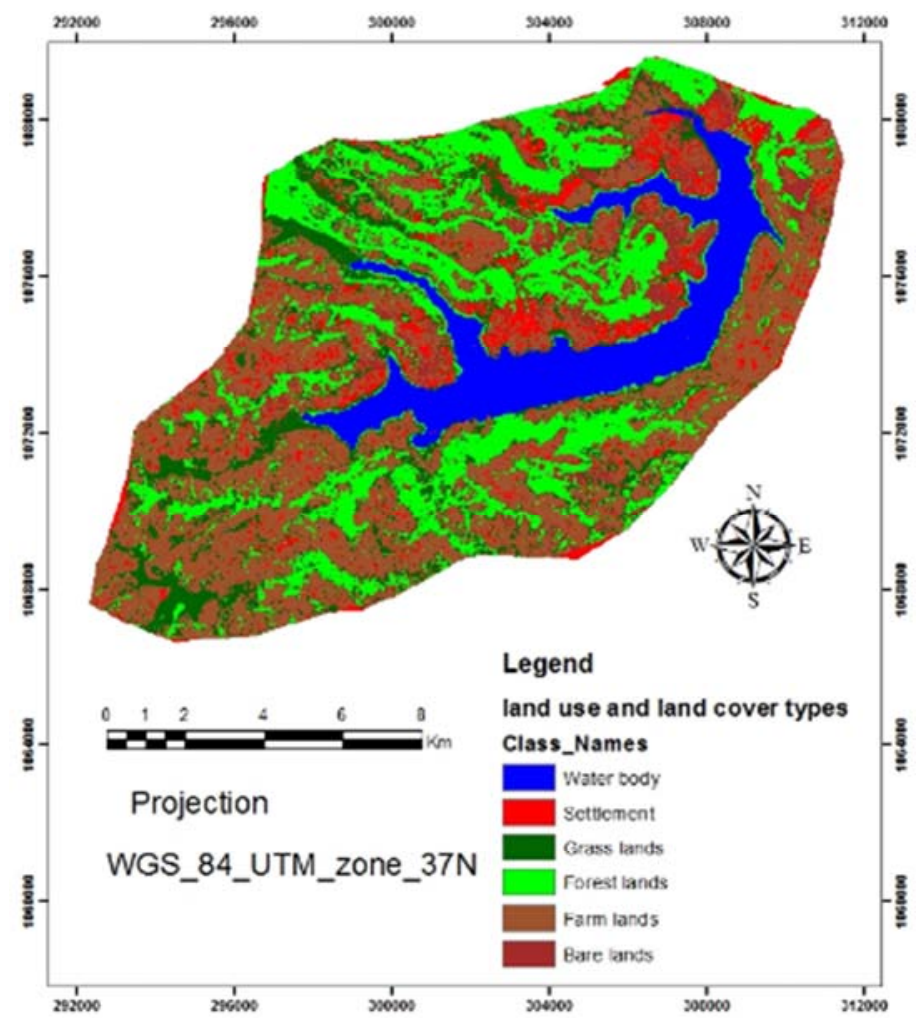

Figure 5. Land use /Land cover types of the study area. 


\subsection{Research Methodology}

The methodology that is used in this soil erosion risk assessment and mapping is the implementation of Revised Universal Soil Loss Equation (RUSLE) in a raster GIS environment (or grid-based approach) after some modifications in the calculation of specific factors. RUSLE is developed as an equation of the main factors controlling soil erosion, i.e., climate, soil characteristics, topography, land cover and land management practice. As cited in [14], (USDA-ARS, 1980), the form of the Revised Universal Soil Loss Equation (RUSLE) is expressed by the formula:

$$
\mathrm{A}=\mathrm{R} \times \mathrm{K} \times \mathrm{LS} \times \mathrm{C} \times \mathrm{P}
$$

Where: $\mathrm{A}=$ estimated average annual soil loss: is the mean annual soil loss caused by sheet and rill erosion; unit are expressed in tones/hectares/years

$\mathrm{R}=$ rainfall erosivity factor: the erosive power of rainfall, expressed in $\mathrm{MJ} \mathrm{mm} / \mathrm{t} / \mathrm{ha} / \mathrm{yr}$

$\mathrm{K}=$ soil erodibility factor; soil resistance against erosive force expressed with ton ha $\mathrm{M} / \mathrm{J} / \mathrm{h} / \mathrm{mm}$

$\mathrm{L}=$ slope length factor; the ration of soil loss from the field

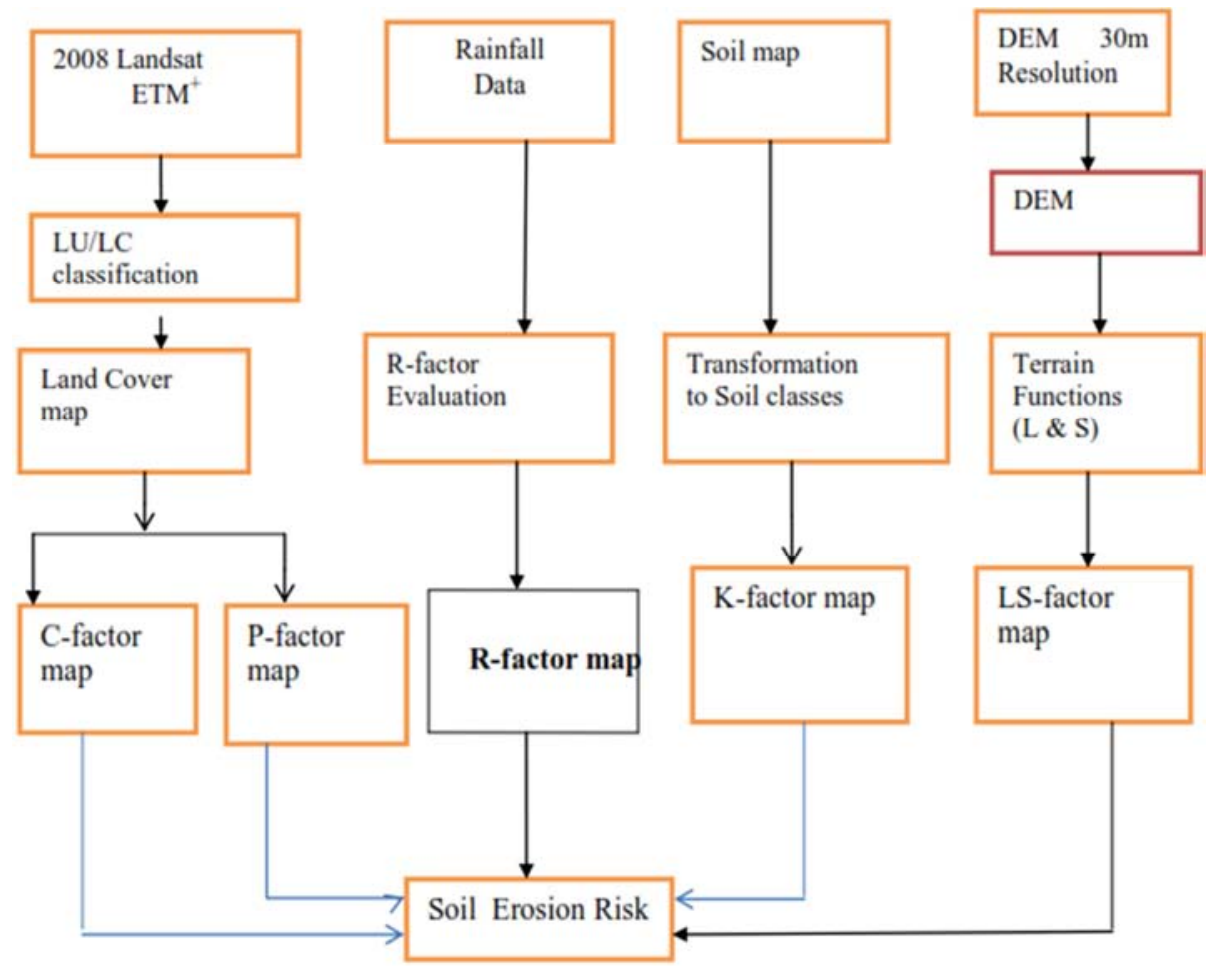

Figure 6. The Scheme of the Methodological steps.

\section{Results and Discusions}

\subsection{Rusle Model Parameters}

1). Rainfall Erosivity factor ( $R$ )

For the study area, the mean annual rainfall data of 11 stations (Alibo, Combolcha, Gebete, Kombolcha, Kachisi, Gida Ayana, Hareto, Homi, Jermet, Neshe and Shambu) over slope length to the soil loss from a $22.1 \mathrm{~m}$ length, under identical condition.

$\mathrm{S}=$ slope steepness factor; the ratio of soil loss from the field slope gradient to soil from a 9\%slope, under otherwise identical condition.

$\mathrm{C}=$ cover management factor; the ratio of soil loss from an area with specified cover and management to soil loss from an identical area with no vegetative cover (dimensionless, ranging between 0 and 1)

$\mathrm{P}=$ conservation practice factor; the ratio of soil loss with support practice, such as contouring, strip cropping or tracing to soil loss with a straight row farming up and down the slope (dimensionless, ranging between 0 and 1 ).

The unit of average annual soil loss (A) are based on the $\mathrm{R}$ and $\mathrm{K}$ factors. The $\mathrm{R}$ factor which represents the erosive power rainfall is considered as the main cause of soil erosion, whilst the erodibility or $\mathrm{K}$ factor represents the soil erodibility or the capability of a particular soil type soil resistance to erosive forces. The other USLE factors (L, S, C, and P) are considered as adjustment factor and they are dimensionless.

20 years $(1996-2016)$ was considered to calculate the R-factor (Table 3).

Rainfall erosivity (R) factor of the RUSLE was estimated from the rainfall data according to the equation given by Hurni [10], derived from a spatial regression analysis (Hellden, 1987), for Ethiopian condition:

$$
\mathrm{R}=-8.12+0.562 * \mathrm{P}
$$


Where $\mathrm{R}=$ rainfall erosivity factor, and $\mathrm{P}=$ mean annual rainfall of the Watershed Reservoir that was collected from National Meteorological Agency.

After the corresponding mean annual rainfall is assigned, the $\mathrm{R}$ value was calculated from the rainfall map using 'Raster calculator" "tool in 'ArcGIS" "software. The raster rainfall data of the study area is converted to erosivity map of the study area using the regression equation.

Owing to variation in mean annual precipitation amount within the study area, variations in rainfall erosivity were observed (Table3). Accordingly, the rainfall erosivity, as estimated from mean annual total rainfall of the respective stations, varied from 1066.16 MJmm/ha.h.yr at Gabate to
1625.87 MJmm/ha.h.yr at Kachisi. The values in Table 3 show that as the mean annual rainfall increases the rainfall erosivity also increases. Following this, the rainfall erosivity is high at the northeast of Neshe and Homi but low to the northwest towards Jermet. Similarly, the rainfall erosivity value estimated from the rainfall map using ArcGIS ranged from 591.06 to $905.62 \mathrm{MJmm} /$ ha.h.yr (Figure 7), which is close to the erosivity values estimated using the mean annual rainfall. According [15], high rainfall may have high erosive power but the total erosivity is not directly proportional to the total amount of rainfall. Therefore, based on this the Northern part of the study area receives relatively higher rainfall that have high erosive power.

Table 3. Rainfall ( $R$-factor of erosivity) of stations.

\begin{tabular}{lll}
\hline Station & Average annual precipitation & R- factor (Erosivity) \\
\hline Shambu & 1443 & 802.85 \\
Alibo & 1215.79 & 675.15 \\
Kombolcha & 1252.22 & 695.63 \\
Fincha & 1614.46 & 899.21 \\
Gebete & 1066.16 & 591.06 \\
Hareto & 1168.63 & 648.65 \\
Homi & 1524.78 & 848.81 \\
Jarmet & 1242.8 & 690.33 \\
Nashe & 1508.97 & 839.92 \\
Kachisi & 1625.87 & 905.62 \\
Gida Ayana & 1498.34 & 833.95 \\
\hline
\end{tabular}

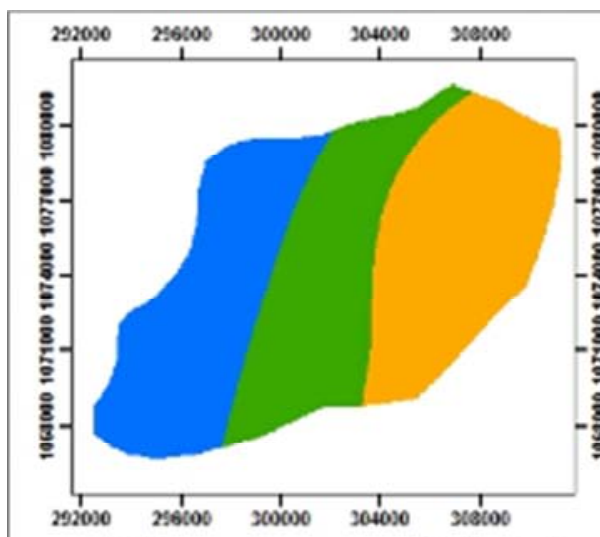

a) Mean Annual Rainfall Legend

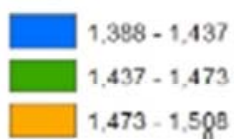

$1,388-1,437$

$1,473-1,5 g^{8} \quad 4$

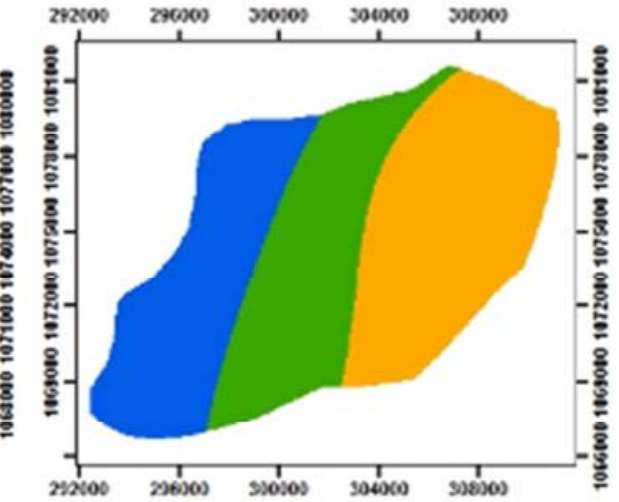

b) R-factor value

Legend

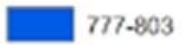

$803-822$

$822-840$

Figure 7. Spatial Variability of Rainfall Erosivity in the study area.

\section{2). Soil erodibility factor $(K)$}

Soil erodibility (K-factor) refers to the liability of the soil to - sufferll erosion due to the forces causing detachment and transport of soil particles. Erodibility varies with soil texture, aggregate stability, shear strength, infiltration capacity and organic matter and chemical content of the soil [5]. In the USLE model, [10] estimated the K-factor values for soil types from the experiment conducted on some six research centers in Ethiopia. For determination of soil erodibility factor (K) Hurni [10] based on soil color.

Black $=0.15$

Brown $=0.20$

Red $=0.25$

Yellow $=0.30$

The major soil types in the study area were extracted from the digital soil map data obtained from the MoA and RDE. 
IDW provides a versatile and simple tool which has sufficient accuracy when used to interpolate continuous surface from scatter point data sources [12]. The resulting shape file was changed to grid file to raster with a cell size of 30 meters resolution.

Table 4. Soil types and there colors in Nashe Dam Watershed and their Erodibility factors.

\begin{tabular}{lllllll}
\hline Soil type & Rhodic Nitisols & Chromic Luvisol & Eutric Vertisol & Eutric leptisols & Haplic Arenosols & Haplic Alisols \\
\hline Soil color & Brown & Red & Yellow & Yellow & Black & Black \\
Erodibility (K-value) & 0.2 & 0.25 & 0.3 & 0.3 & 0.15 & 0.15 \\
\hline
\end{tabular}

From the digital soil map data Eutric Vertisols, Chromic Luvisols and Rhodic nitosols were recognized and obtained from MOA in the study area. These soil types were assigned with suitability values for further processing. Chromic Vertisols contain much exchangeable Aluminum and are notorious for inactivating fertilizer phosphate. Nitosols are the most fertile productive soils and have a potential under rain-fed agriculture. Nitosols are found in northern, Eastern, southern and Southwestern. It covers majority of the study area. Chromic Luvisol are found in northern, Central and southeastern corner of the study area.

As can be seen from (figure 9) the soil erodibility values of the study area ranged from $0.15 \mathrm{t} / \mathrm{ha}$.yr, the lowest to 0.25 tons/hac/MJmm, the highest. The Erodibility values were found to be consistent in the northern central parts, western and southwestern parts of the study area. This indicates that the soils are highly vulnerable to erosion because they have low aggregate stability and low infiltration rate which may lead to high runoff soil loss, namely Rhodic Nitisols, Chromic Luvisols and Eutric Vertisols by comparing (figure 4 and 5). The soils which area found in the northern, Eastern, southern and Southwestern parts of the study area have relatively low $\mathrm{K}$-factor values (figure 8), that indicates resistance to erosion. Although the highest $\mathrm{K}$-factor value of the study area $\mathrm{K}=0.25$, is relatively low compared to the standard maximum value $(\mathrm{K}=1)$. Medium textured soils, such as silty loam soils have a moderate $\mathrm{K}$ values, because they are moderately susceptible to detachment and they produce moderate runoff. Soils having high silt content $(\mathrm{K}=1)$ are the most erodible of all soils as they cause a decrease in filtration [3]. Hence, soil loss in the study area is expected to be relatively low compared with areas that may have a K-value close to maximum.

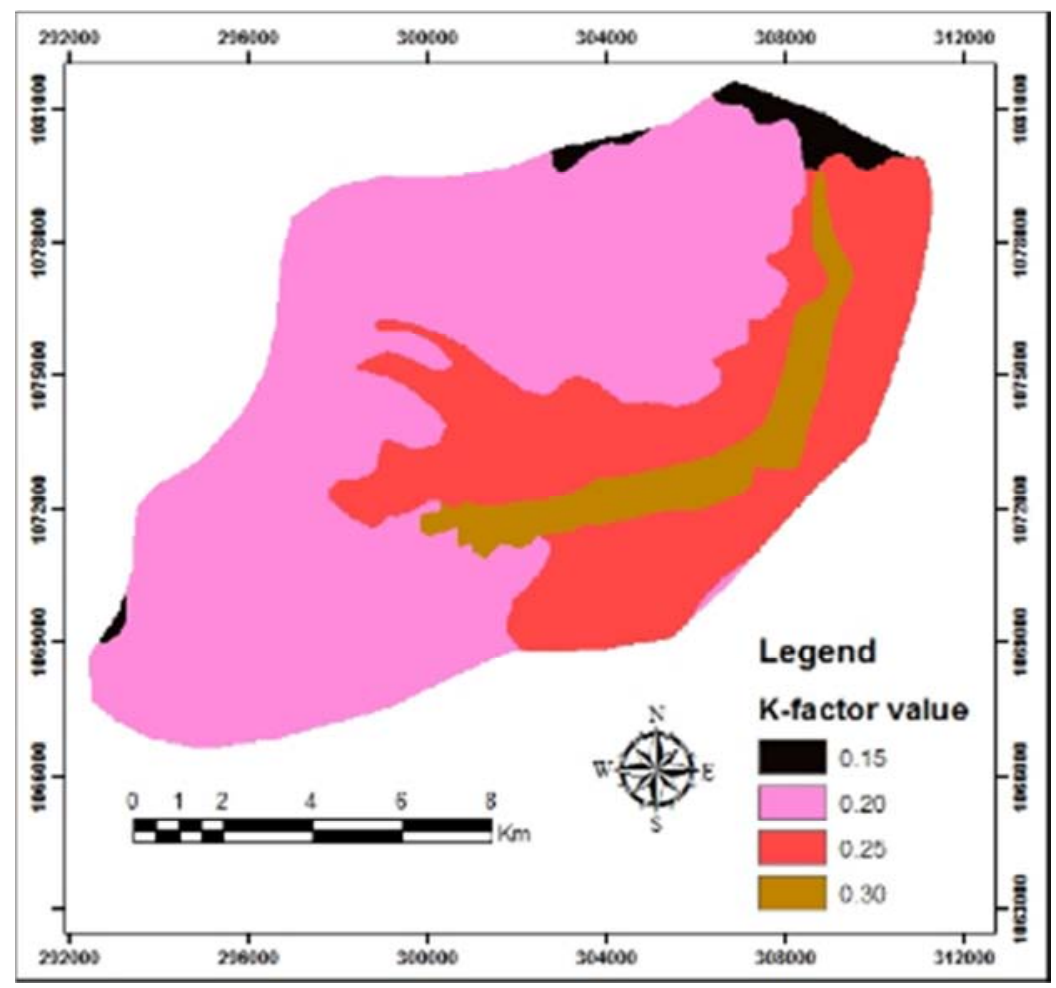

Figure 8. Map of the spatial Variability of the soil erodibility (K) factor of the study area.

\section{3). Slope length and steepness factors (LS)}

Slope Length and Slope gradient (steepness) has been obtained from the DEM-SRTM of the study area. The elevation of the study area ranges from 1907 to 2564 meters above sea level (Figure 10). Low values of the elevation are found on the west corner, southwest central and northeastern part of the study area. High values of the elevation were also obtained in the northeastern corner and southwestern part of the study area. High slope length and slope steepness factor values were obtained in areas with steep and long slopes.

According to [1], erosion would normally be expected to increase in slope length and slope steepness factor as a result of respective increases in velocity and volume of surface runoff. Steeper slope causes higher runoff velocities, more splashes 
downhill and faster flow and therefore contributes greater soil erosion. Based on these, since the study area is located in the midland and highlands (with altitude greater than $1500 \mathrm{~m}$ a.s.1.) it may have a great contribution in soil loss by water erosion.

The effect of topography on erosion in RUSLE is accounted for by the LS factor. Erosion increases as slope length increases, and is considered by the slope length factor (L). Slope length is defined as the horizontal distance from the origin of overland flow to the point where either the slope gradient decreases enough that deposition begins or runoff becomes concentrated in a defined channel [5].

The slope steepness factor $(\mathrm{S})$ reflects the influence of slope gradient on erosion. Both slope length and steepness substantially affects sheet and rill erosion estimated by RUSLE. In erosion prediction, the factors $\mathrm{L}$ and $\mathrm{S}$ are usually evaluated together. In this study, the slope gradient was determined from digital elevation model (DEM) of 30 meter resolution. The slope gradient determined for the study area is used for generating the LS factor as determined by SCRP for Ethiopian condition.

Erosion is influenced both by the slope gradient and length of the slope, the potential erosion on uniform slopes increases as these parameters increase. The new RUSLE equation has major changes in way that LS values are calculated. The assumptions taken into consideration are as follows:

The USLE assumed that runoff was uniform over the catchments and that some runoff was channeled into rills and gullies; rill erosion is a major component in the RUSLE.
The USLE calculated the amount of runoff as the excess applied minus soil infiltration but did not consider that long rains would saturate the soil, infiltration would be slower and runoff, which causes erosion, would be greater.

Sediment deposition at the bottom of concave slopes was not considered, USLE being applied only to those areas with net erosion.

The USLE was not designed to handle converging and diverging terrain; this has been rectified in the RUSLE.

Several methods of LS factor determination is developed with different GIS professionals at different time. These includes; using the formula: $\mathrm{LS}=($ flow accumulation * DEM cell resolution/22.13)0.6* ( $\sin ($ slope $* 0.01745) / 0.09) 1.3$ and $\mathrm{LS}=\lambda 0.3 / 22.1 / 22.1)^{*}(\mathrm{~S} / 9) 1.3$. For this study calculating LS factor by using DEM after preparing the flow direction and flow length map of the following formula (Equation 3) was used.

$$
\mathrm{LS}=(\lambda 0.3 / 22.1) *(\mathrm{~S} / 9) 1.3
$$

$\mathrm{LS}=($ pow $($ flow length, 0.3$) / 22.1) *$ pow $($ slope $/ 9,1.3)$

Where; $\lambda=$ Flow length, $\mathrm{S}=$ Slope in percent

In raster calculator two steps was followed:

Determination of $(\lambda 0.3) *(\mathrm{~S} / 9) 1.3$

Division of the result of step one by 22.1

The LS value is considered to have values between 0.02 48 for Ethiopian condition (Hurni, 1985) and the study area are ranging from 0 to 12.03 .

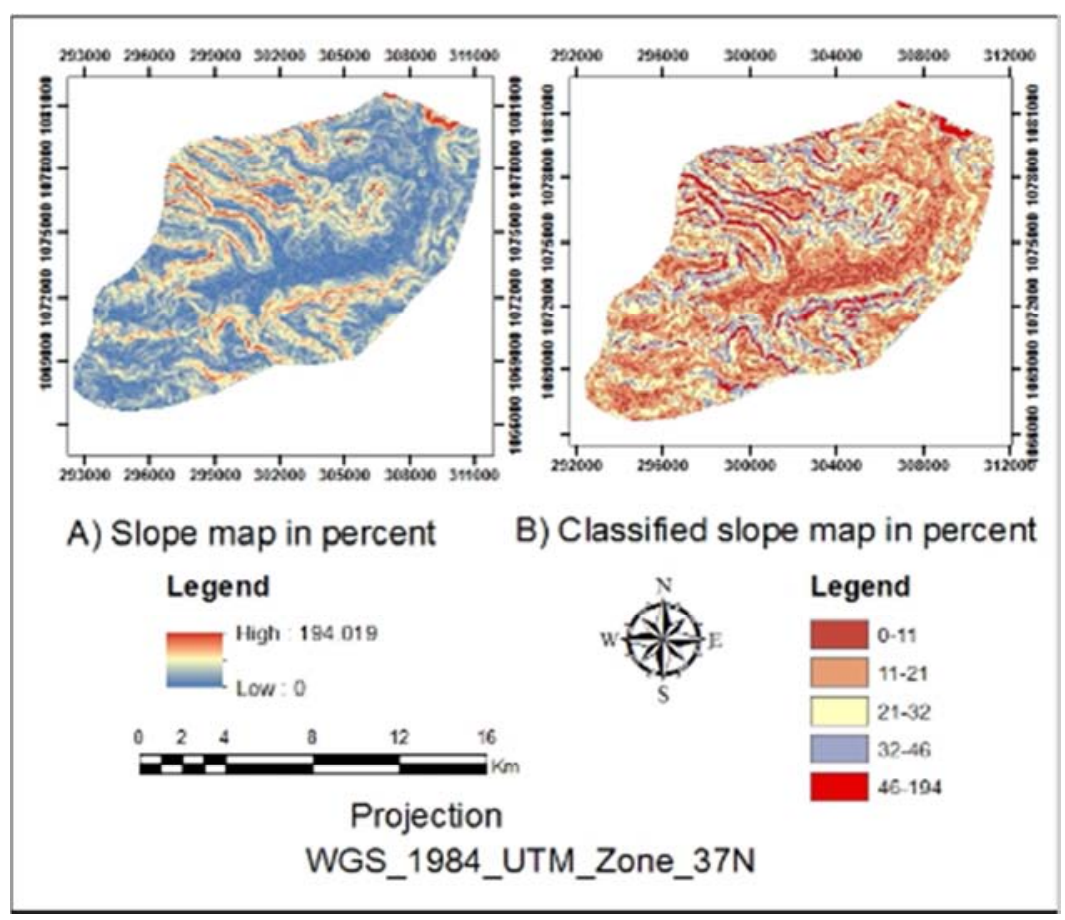

Figure 9. Slope map of the study area.

The basic input for generating an LS factor grid in GIS is a DEM dataset of suitable scale that has been clipped to encompass the zone of interest, usually a topographically defined catchment or watershed. Therefore, for this study the slope gradient in percent (Figure 9) was determined from ASTER digital elevation model (DEM) of 30 meter resolution. Slope gradient (\%) used to generating LS factor combined with slope length $(\mathrm{m})$ and slope steepness (S) produce LS factor as determined by SCRP for Ethiopian condition.

Thus, producing the LS factor map (Figure 10) based on the value assigned to each slope classes by SCRP for Ethiopian 
indicated as below (Table 5).

Table 5. LS factor value for each slope classes.

\begin{tabular}{lllllllllll}
\hline Gradient in percent & $<\mathbf{2}$ & $\mathbf{2 - 4}$ & $\mathbf{4 - 6}$ & $\mathbf{6 - 8}$ & $\mathbf{8 - 1 3}$ & $\mathbf{1 3 - 1 5}$ & $\mathbf{2 5 - 4 0}$ & $\mathbf{4 0 - 5 5}$ & $\mathbf{5 5 - 1 0 0}$ & $>\mathbf{1 0 0}$ \\
\hline LS factor value & 0.19 & 0.38 & 0.66 & 1.14 & 1.9 & 3.8 & 6.08 & 7.98 & 10.45 & 19 \\
\hline
\end{tabular}

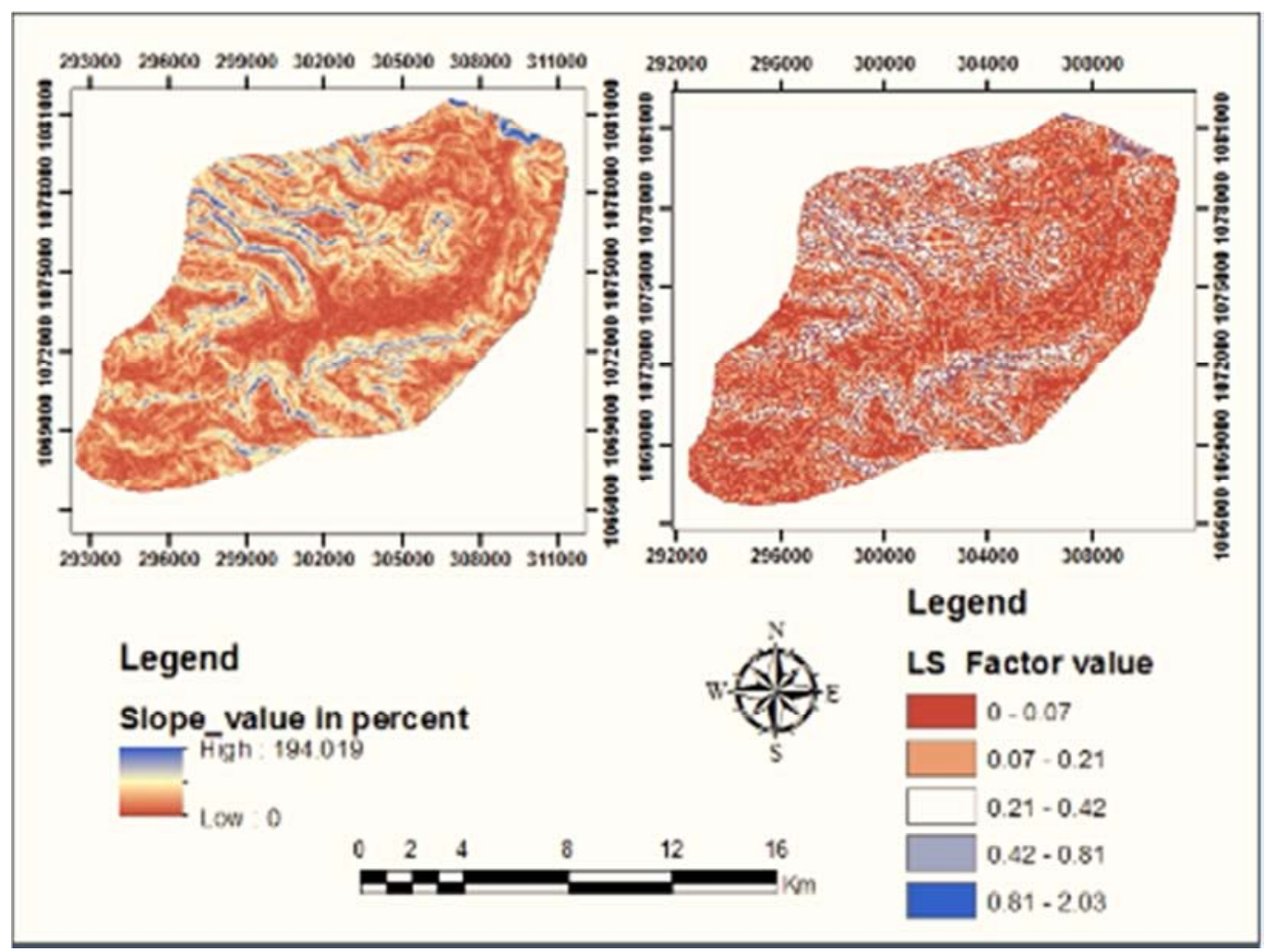

Figure 10. Slop Map and LS factor Value Map.

\section{Land use/land cover factor $(C)$}

The $\mathrm{C}$-factor is defined as the ratio of soil loss from land with specific vegetation to the corresponding soil loss from continuous fallow with the same rainfall [5]. The type of land cover (crop type) and tillage make the greatest difference in the amount of erosion that occurs in a given area. For this reason up-to-date and accurate land use/land cover map was used for analyzing the $\mathrm{C}$-value Remotely sensed data was used to estimate the $\mathrm{C}$-factor distribution based on land-cover classification results, assuming that the same land covers have the same $\mathrm{C}$-factor values.

The land use/cover area was derived from a supervised of the study land cover classification of the Landsat satellite image 2016 and was verified with field observation to representative sites of the study area. After getting the classified image, it was changed in to vector format and the corresponding C-value was obtained from [10] and C- factor map was produced.

Over the study area, it has been realized that in the study area maize (Zea mays, L.), sorghum (sorghum bicolor, L.)), 'teff' (Eragrostis teff, L.), 'neug', oat and others are the dominantly grown crops. Most of these crops are categorized under moderately cultivated land use/land cover. From the 2016 year's Landsat image extract, C-factor values were assigned to each of the land use/land cover classes recognized over the study area (Table 3). In order to identify specific values for each land use/cover category, the image data was classified into five categories.

As shown in Figure 11, the estimated Cover Management (C) factor of the study area shows that northeastern corner, Central and Northern corner parts were covered by grassland which has low $\mathrm{C}$-factor values. Most parts of the lands in the area are intensively cultivated farmlands. It was exposed to erosion because the higher the $\mathrm{C}$-factor, the higher the soil loss will be. Forest land is found in the west and northwestern corner and also in central part of the study area having low $\mathrm{C}$-factor values, whereas the moist land is found in southwestern part.

In general, Vegetation reduces soil erosion by: protecting the soil against the action of falling raindrops, increasing the degree of infiltration of water into the soil, reducing the speed of the 35 surface runoff, binding the soil mechanically, maintaining the roughness of the soil surface, and improving the physical; chemical and biological properties of the soil [12]. Therefore, soil cover in the form of crop plants, cover crops, mulches, or residues can protect soils from wind and water erosion, enhance water infiltration, and help maintain or increase organic matter [6]. Thus, they have low C-factor values that have low contributions to the soil loss. 


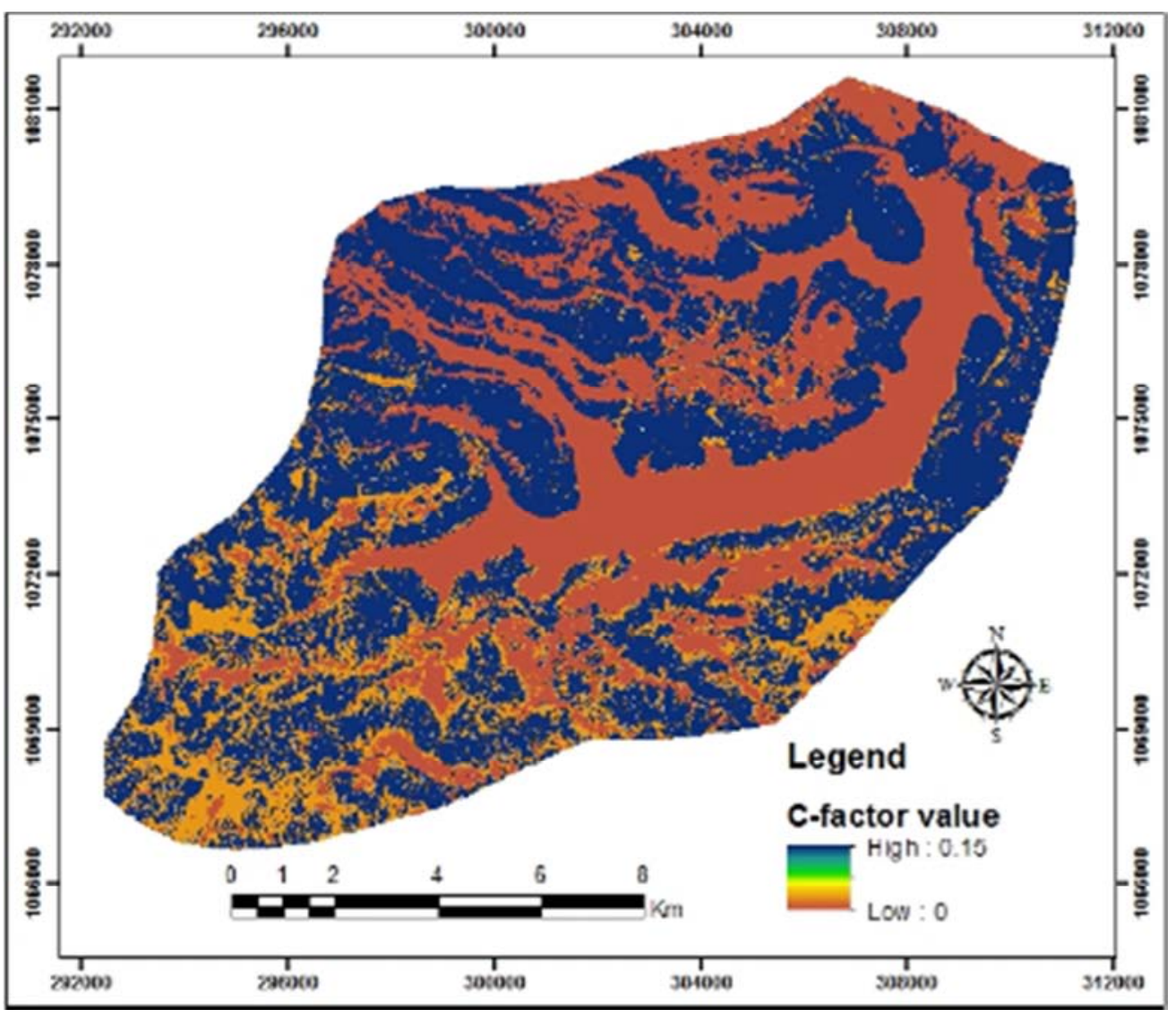

Figure 11. C-factor Values map of the study area.

The $\mathrm{C}$-factor values which represents the vegetation cover of the area vary from 0 to 1 . The highest value of 1 was assigned to bare lands [2] whilst the value 0 was designated to the water areas. The Forest cover was given the value of 0.005 . In some studies [7], the C-factor value varies from 0.001 to 0.010 depending on the type and condition of the forest.

The C-factor values (Figure 11), of the study area range from 0.001 to 0.15 . The $\mathrm{C}$-factor values were high in the intensively cultivated land. The low $\mathrm{C}$ - factor values were 0.001 that were found to northeastern corner, western corner, southwestern corner and southeastern part of the study area.

In general vegetation reduces soil erosion by protecting the soil against the action of falling rain drops, increasing the degree of infiltration of water into the soil, reducing the speed of the surface runoff, binding the soil mechanically, maintaining the roughness of the soil surface, and improving the physical, chemical and biological properties of the soil [12]. Therefore, soil cover in the form of the crop plants, cover crops, mulches, or residues can protect soils from wind and water erosion, enhance water infiltration and help maintain or increase organic matter [6]. Thus they have low C- factor values that have low contribution to the soils.

The $\mathrm{C}$-factor values (figure 11) of the study area ranges from 0.00 to 0.15 . The $\mathrm{C}$ - factor values were high in the intensively cultivated lands. The low C-factor Values were 0.001 that were found to northern corner, western corner, south western corner and south eastern part of the study area.

Management (support) practice factor $(P)$
From the 2016 satellite image extracted, P-factor values were assigned to each of support practice $(\mathrm{P})$ classes recognized over the study area (Table 6). In order to identify specific values for each management practice category, the image data was classified into two major categories (Figure 12). The P-factor values of the study area ranged from 0.7 to 0.9. The P-factor values were found to be low in the corner of northeastern, western, northwestern and southwestern part of the area but in most part of the midland and highland the P-factor values were high.

In general, as shown in Table 6 and Figure 12, the open land and cultivated land of the study area have relatively high $\mathrm{P}$-values $(\mathrm{P}=0.9)$, whereas the grassland, dense forest land and moist land have low $\mathrm{P}$-values $(\mathrm{P}=0.7)$. The estimation of the P-factor values for the study area was carried out taking into account the local management practices. Practices that maintain soil cover include minimum tillage, cover cropping, managed grazing, contour planting, strip cropping, crop rotation, control structures and diversions to protect soils from water erosion by decreasing the effective slope length along a field. Land use classification is often used to map vegetation types that differ in their effectiveness to protect the soil. The factor takes into account the use of farming techniques as contour plowing and terracing that tend to decrease soil erosion. It was observed that, in almost all the areas, farmers plough their farmlands in different directions with traditional ox drawn sub soiled ploughs that penetrate into and scratch the soil many times before broadcasting the seed. graded bunds 
and contour Ploughing.

Table 4. Management Practice factor which adapted to Ethiopian condition.

\begin{tabular}{llll}
\hline No & slope & Contouring & Terracing and contouring \\
\hline 1 & $1-2$ & 0.6 & 0.1 \\
2 & $3-5$ & 0.5 & 0.1 \\
3 & $6-8$ & 0.5 & 0.1 \\
4 & $9-12$ & 0.6 & 0.12 \\
5 & $13-16$ & 0.7 & 0.14 \\
6 & $17-20$ & 0.8 & 0.16 \\
7 & $>20$ & 0.9 & 0.16 \\
\hline
\end{tabular}

Source: (Bewket and Teferi, (2009) and Wischmeir and Smith (1978).

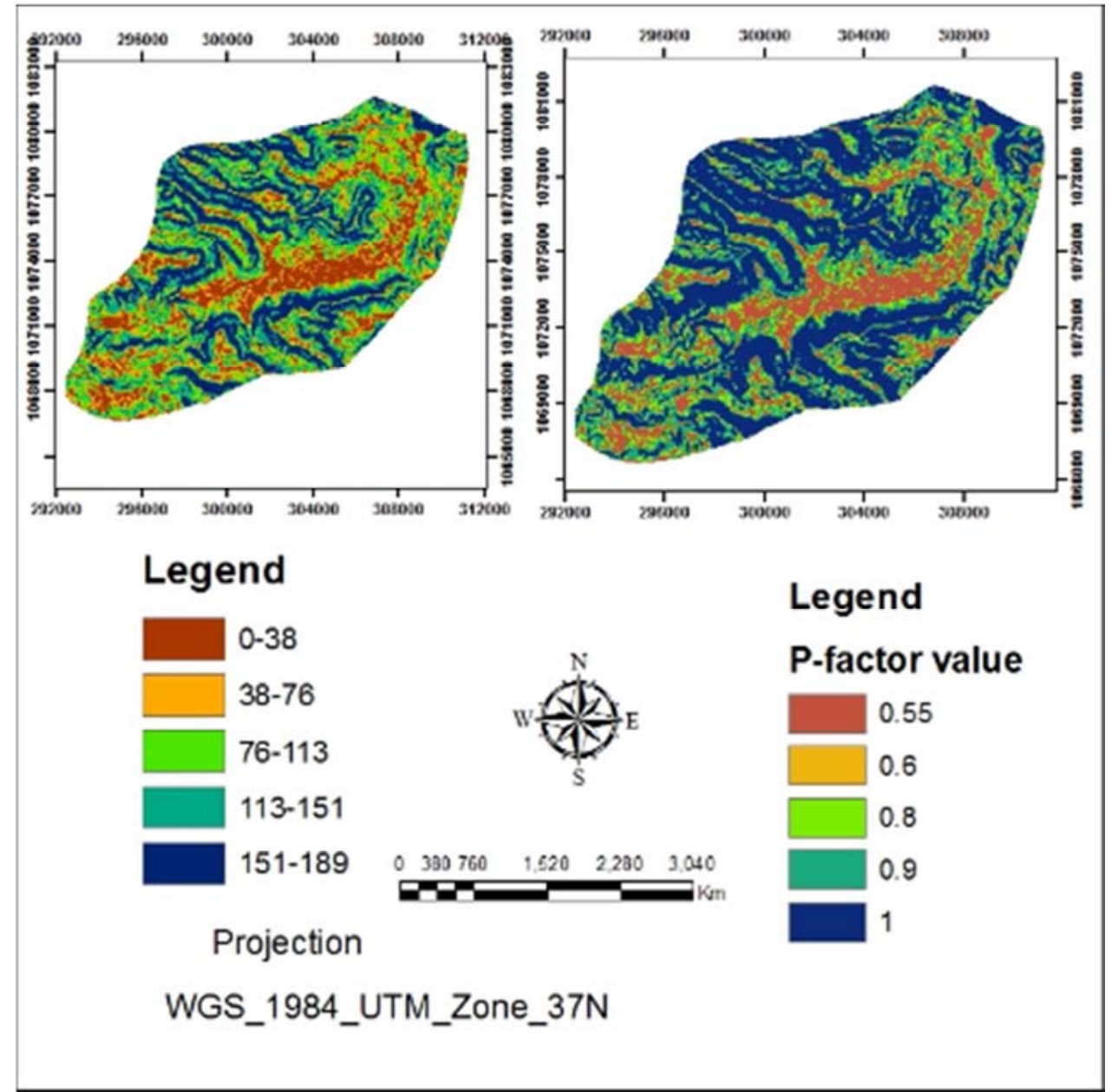

Figure 12. Variation of the Estimated P-factor values for the study.

\subsection{Status of Soil Loss in the Study Area}

The RUSLE model estimates the amount of annual soil loss as a function of the parameters. As can be seen from the statistics and map output of the cell to cell multiplied parameter layers, the study area has significant levels of annual soil loss as a function of: rainfall erosivity (R), soil erodability (K), slope gradient (S), slope length (L), cover management $(\mathrm{C})$ and support practice $(\mathrm{P})$ factors. that vary from $0.00 \mathrm{t} / \mathrm{ha}$.yr, the lowest, to $243.065 \mathrm{t} / \mathrm{ha} / \mathrm{yr}$, the highest.

This is the real indicator of the existence of risk of soil erosion in the area. In general, low potential soil losses were mostly found in the northeastern, western and southwestern parts of the study area, which is closely associated with the relatively less susceptibility of the soils of those areas to erosion, and low $\mathrm{C}$-factor values. On the other hand, the estimated soil loss showed an increasing trend towards the central parts of the northeastern, southern and southwestern parts of the area, which might be attributed, among others, to the dominance of soils with high susceptibility to erosion (Figure 14 and Table 7). Accordingly, the results obtained clearly indicated that the north and the northeastern central parts of the District are highly susceptible to erosion and require immediate attention. 


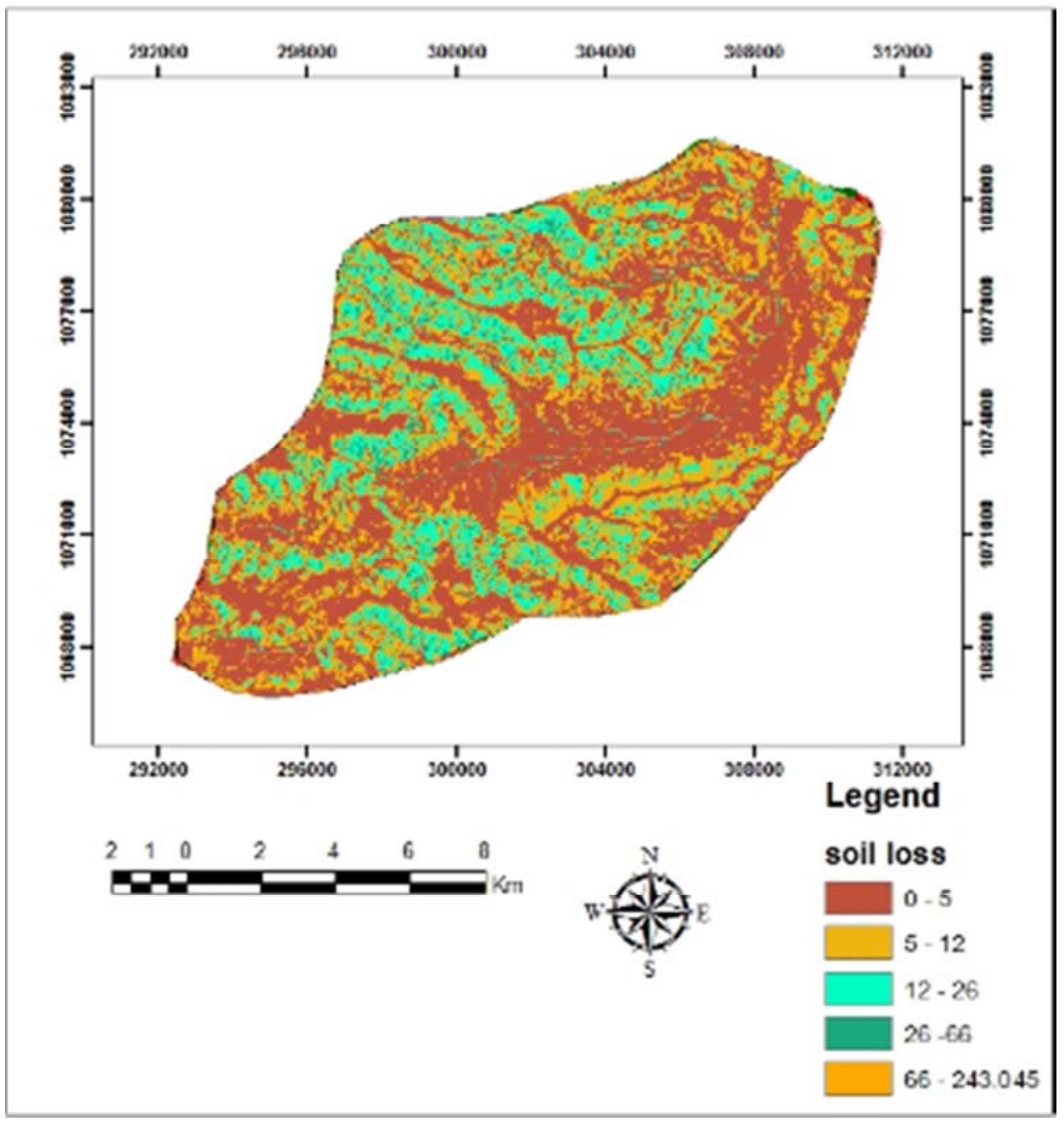

Figure 13. Status of soil loss.

\subsection{Land Use Land Covers Change}

There are six major land use land cover classes have been identified including forest, settlement, bare land, water body, farm land and grass land. The land use land cover changes comparisons over the study years is below.

Table 7. Change of the land use land cover classes for two different years.

\begin{tabular}{|c|c|c|c|c|c|}
\hline \multirow{2}{*}{ No } & \multirow{2}{*}{ Land use land cover } & \multicolumn{2}{|l|}{1996} & \multicolumn{2}{|l|}{2016} \\
\hline & & Area $\left(\mathrm{Km}^{2}\right)$ & $\%$ & Area $\left(\mathrm{Km}^{2}\right)$ & $\%$ \\
\hline 1 & Water body & 12.40 & 7.06 & 21.27 & 12.10 \\
\hline 2 & Forest land & 82.79 & 47.10 & 39.99 & 22.75 \\
\hline 3 & Grass land & 15.55 & 8.85 & 12.04 & 6.85 \\
\hline 4 & Settlement & 7.77 & 4.42 & 13.34 & 7.59 \\
\hline 5 & Farm lands & 47.76 & 27.18 & 80.06 & 45.55 \\
\hline 6 & Bare lands & 9.48 & 5.40 & 9.05 & 5.15 \\
\hline Total & & 175.75 & 100 & 175.75 & 100 \\
\hline
\end{tabular}

The LULC in the study watershed have undergone modifications and conversions over the study years (Figure 14). In 1996, forest land, grass land and farm land constituted a relatively large proportion about $(47.10 \%),(8.85 \%)$ and (27.18) respectively. Besides, a relatively considerable amount of the area was covered by settlement $4.22 \%$, bare land and water body are $12.46 \%$. These conditions were considered as a baseline for change detection over the study period (Figure 14). After 20 years, forest and grass land have been declined to $22.75 \%, 6.85 \%$ respectively. In contrast there is large expansion on farm land which accounts $(45.55 \%)$. Also settlement and water body increased to $7.55 \%$ and $12.10 \%$ respectively (Figure 14 ). 


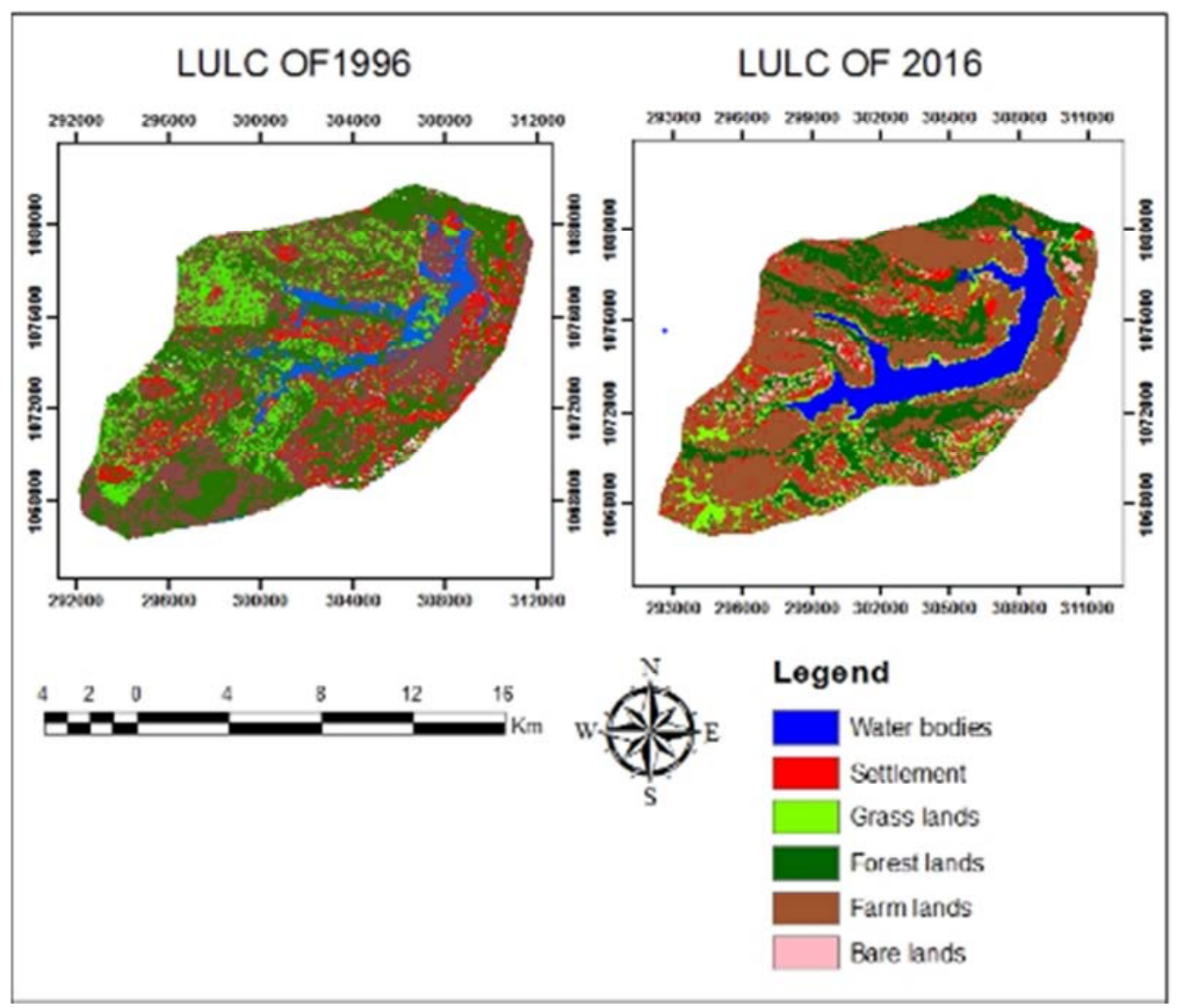

Figure 14. Land use land cover map for year1996 (a) and 2016 (b).

B. Erosion rates per slope classes

Erosion rates in different slope classes for the watershed areas were also determined. As shown in (figure 15). Average erosion rates at watershed increases as slope increases. The average erosion rates are lowest in flat areas, which ranges from 5 to 24 ton/ha/yr and the highest rate is found in the very steep classes between 16 to 320 to/ha/yr. (table. Erosion rates per slope classes). Soil erosion rates increased with an increase in slope steepness, as a result of faster water flow [2].

Table 5. Slope classes per erosion rates.

\begin{tabular}{lll}
\hline No & Slope in degree & Erosion rates (tone/ha/yr) \\
\hline 1 & Flat (0-5) & 9 \\
2 & Gently sloping $(5-10)$ & 25 \\
3 & Moderate slope $(10-17)$ & 59 \\
4 & Steep slope $(17-24)$ & 234 \\
5 & Very steep slope $(>24)$ & 320 \\
\hline
\end{tabular}

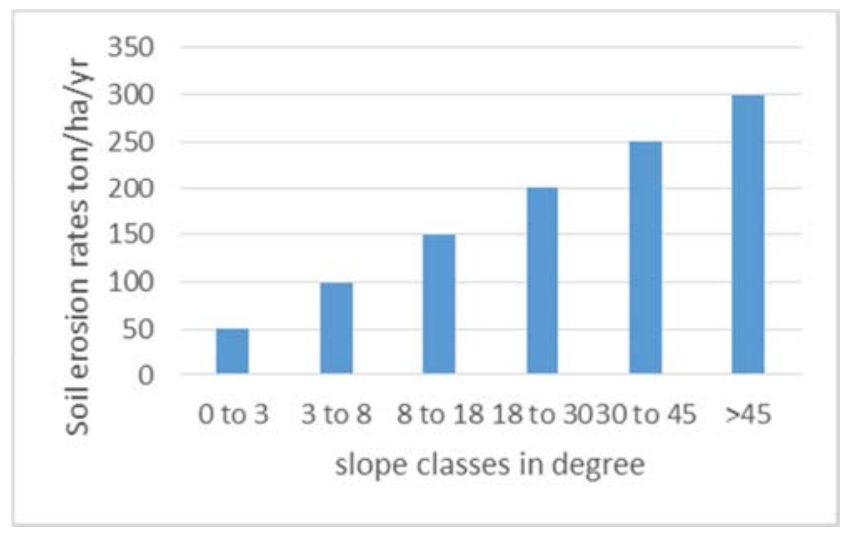

Figure 15. Average erosion rates per slope classes.

Table 5. Erosion Rates per slope class.

\begin{tabular}{ll}
\hline Slope classes in degree & Erosion rate (tone/ha/yr) \\
\hline $0-3$ & 0 \\
$3-8$ & 50 \\
$3-18$ & 100 \\
$18-30$ & 150 \\
$30-45$ & 200 \\
$>45$ & 350 \\
\hline
\end{tabular}

At the watershed, averages erosion rates shown an increasing pattern from flat to steep classes, the average erosion rates increases from flat to moderate classes. However, a drop in the average soil loss can be observed for the very steep classes at the northern area and for the high and very steep classes at the southern area. These drops in the average erosion rates for the southern and northern sites could be 
attributes to land cover. The land cover for the very steep areas at eastern and for the high and very steep areas at western sites are predominantly forest. This has mitigated the impact of the factors such as the LS factors which are usually higher on the steep areas.

In contrast, the extremely high erosion rates, at the high and very steep areas of the southern and northern sites could be ascribed to the presence of the bare lands which are likely to have a high potential risk of erosion. This disparity in the results illustrates the importance of the vegetation cover to protect the soil from excessive erosion.

Furthermore, erosion rates are expected to be higher as slope steepness rises and thus land disturbances should minimized or prevented.

\section{Conclusion}

Soil erosion is a serious problem in the highlands of Ethiopia and attempting different methods to evaluate soil loss at the watershed scale is necessary for planning of soil erosion protection and conservation measures, which are necessary for sustainable land use and development.

RUSLE is often used to estimate average annual soil loss from an area. RUSLE model in GIS environment is a relatively simple soil erosion assessment method. GIS is valuable tool for soil erosion risk estimation and prediction. With proper selection of digital elevation models, satellite imagery indices

and appropriate methodology, very objective results can be achieved.

GIS-based soil erosion risk assessment, minimizes subjective errors of the traditional (classical) estimations, and maximizes the possibilities for different uses and spatial computation. To adopt the RUSLE, large sets of data starting from rainfall, soil, slope, crop, and land management are needed in detail. This paper attempts to evaluate soil losses and map the area susceptible to the soil erosion in Nashe dam Watershed by means of satellite images and Geographic information system tools. The average annual soil loss in the Nashe dam watershed area was computed by overlaying the five factor maps using RUSLE with Spatial Analyst extension. The average annual soil loss ranged from 0.01-300 tons ha $-1 y-1$ the mean value is 45.7 ton ha

Land use land cover is one of the important factors that used to minimize soil erosion. Based on this having knowledge about changes occurs on land use land cover features is effective for soil and water conservation. In this area there are unsustainable land use land cover practices aggravated by continuous deforestation and soil erosion.

The finding of the land use land cover change over the last two decades showed that vegetation covers in different forms decline year after year, except dense forest area. Grass land decline from $(30.81 \%)$ to $(21.4 \%)$, open forest changes from $(36.37 \%)$ to $(16.66 \%)$ and bush and shrub land changes from $(2.36 \%)$ to $(1.25 \%)$. Quite the opposite areas which occupied by farm land, dense forest and water body increase to $(53 \%)$, $(4.62 \%)$ and $(2.45 \%)$ respectively.

\section{Recommendation}

The assessment of soil erosion risk using remote sensing and GIS techniques was conducted in Nashe dam reservoir Catchment, Abay choman District, Oromia region, western Ethiopia. The objective of the study was to investigate areas prone to high risk of water erosion and to map the spatial variability of erosion in the study area and the prioritization of conservation priority categories, which can be used for preparation of a conservation plan for management of the watershed. In particular, the assessment and mapping of soil erosion risk was set out to indicate evidence that accounts for a decline in soil fertility due to water erosion and this decline is related to socio-economic status of the farmer and the type of land use.

The analysis was carried out using RUSLE model which is an empirically based model that has the ability to predict the long term average annual rate of soil erosion on a field slope as a result of rainfall pattern, soil type, topography, crop system and management practice. The evaluation of soil loss estimation requires an understanding of the contribution of each of the parameters controlling the erosion process.

The spatial variability of rainfall erosivity in the study area estimated from rainfall data covering a period of nineteen years ranged from $801.6 \mathrm{MJmm} / \mathrm{ha}$.h.year in the mid altitude to $982.3 \mathrm{MJmm} /$ ha.h.year in the highland. Erodibility values were generally low over the study area. It ranged in between 0.00 and 0.25 ton.ha.h/ha/MJmm in the north central parts, eastern and south western parts of the study area. Soils having high silt content $(\mathrm{K}=1)$ are the most erodible of all soils as they cause a decrease in infiltration.

The result of map output of the cell to cell multiplied parameter layers show that the study area has significant levels of soil loss estimation that varies from about 0.00 to $243.065 \mathrm{t} / \mathrm{ha} / \mathrm{yr}$. This estimated soil loss for the study area is within the range of soil loss estimated for the Ethiopian highlands by the Soil Conservation Research Project (SCRP) which ranges from 0.00 to $300 \mathrm{t} / \mathrm{ha}$.yr.

\section{References}

[1] Deore. (2005). Prioritization of Micro-watersheds of Upper Bhama Basin on the Basis of Soil Erosion Risk Using Remote Sensing and GIS Technology. PhD thesis, University of Pune, Pune.

[2] Morgan. ((1995).). Morgan, R. P. C., (1995). Soil Erosion and Conservation. Edinburgh: Addison-Wesley Longman.

[3] Saavedra. (2005). Estimating spatial patterns of soil erosion and deposition in the Andean region using geo-information techniques: a case study in Cochabamba, Bolivia Ph.D dissertation, Wageningen University, The Netherlands.

[4] Mulugeta. (2004). Effects of land use change on soil quality and native flora degradation and restoration in the high lands of Ethiopia. Implication for sustainable land management. Swedish University of Agricultural Science. Uppsala, Sweden. 
[5] Wischmeier and Smith. (1978). W. H., D. D., (1978). Predicting rainfall erosion losses, a guide to conservation planning. Agric. Hand B. No. 537, US Department of Agriculture,. conservation planning. Agric. Hand B. No. 537, US Department of Agriculture, Washington, DC.

[6] Bobe (2004). Evaluation of Soil Erosion in the Harerge Region of Ethiopia, Using Soil Loss Models, Rainfall Simulation and Field Trials, $\mathrm{PhD}$ thesis, University of Pretoria, etd.

[7] Breiby. (2006). Assessment of Soil Erosion Risk within a Sub watershed using GIS and RUSLE with a Comparative Analysis of the use of STATSGO and SSURGO Soil Databases. Volume 8, Papers in Resource Analysis. Saint Mary's University of Minnesota Central SMinnesota Central S.

[8] FAO 1986; Sutcliff. (1993). Economic assessment of land degradation in the Ethiopian highlands: Acase study. National conservation strategy secretariat, Ministry of planning and economicdevelopment, Addis Ababa, Ethiopia.

[9] Hurni. (1985). The Design and Construction of Small-scale Earth Micro-dams. A fieldmanual for assistant technicians working under the supervision of agriculturalor irrigation engineers. Addis Ababa: Soil Conservation Research Project, Ministry of Agricultur.
[10] Lillesand \& Kiefer. (1994). Remote Sensing and Image Interpretation. Third edition. Printed in the United States of America.

[11] De Asis and Omasa. (2007). Estimation of vegetation parameter for modeling soil erosion using linear Spectral Mixture Analysis of Landsat ETM data. ISPRS Journal of Photogrammetry \& Remote Sensing 62, 309-324.

[12] Hellden. (1987). An Assessment of Woody Biomass, Community Forests, Land Use and Soil Erosion in Ethiopia. Lund University Press.

[13] Renard. (1996). Renard, K. G., Foster, G. R., Weesies, G. A., Predicting soil erosion by water: a guide to conservation planning with the Revised Universal Soil Loss Equation (RUSLE). Agriculture Handbook No. 703. Agricultural Research Service, Washington, DC.

[14] Hudson. (1981). The Factors Determining the extent of Soil Erosion; \| In Green Land J. D and Lal R. (ed), Soil Conservation and Management in the Humid Tropics; John Wiley \&Sons Ltd, Great Britain. 